\title{
A NEW SPECIES OF HALACARSANTIA (CRUSTACEA, ISOPODA, ASELLOTA) FROM SISAL CORAL REEF SYSTEM, YUCATAN, MEXICO
}

\author{
MANUEL ORTIZ, MARILYN SCHOTTE, IGNACIO WINFIELD
}

\begin{abstract}
The family Santiidae consists of five genera and 29 species at present, included in the Suborder Asellota. In the northwest Atlantic this family is represented only by the genera Santia (two species), Halacarsantia (one species) and Spinosantia (one species). The present paper deals with the description of a new species of the genus Halacarsantia, collected at the Sisal Coral Reef System, Yucatan, Veracruz. The new species of Halacarsantia represents the $29^{\text {th }}$ asellote isopod discovered in the Gulf of Mexico and brings the total number of species of Halacarsantia to eight. The main differences between the new species and all others in the genus are: mandibular palp present; frontal lobe $0.5 \times$ as wide as maximum width of head, with 18 robust setae; coxae of all pereopods dorsally visible; eyes directly settled on each sides of head. A key to the species of Halacarsantia is included.

Résumé. La famille Santiidae regroupe actuellement 29 espèces appartenant aux cinq genres dans le sous-ordre Asellota. Dans l'Atlantique Nord-Ouest cette famille est représentée uniquement par le genre Santia (2 espèces), Halacarsantia (1 espèce) et Spinosantia (1 espèce). Cet article traite la description d'une nouvelle espèce du genre Halacarsantia collectée au Sisal Coral Reef System, Yucatan, Veracruz. La nouvelle espèce de Halacarsantia représente le 29e Isopode Asellote découvert dans le golfe du Mexique et monte le nombre total d'espèces de Halacarsantia à huit. Les principales différences entre la nouvelle espèce et tous les autres du genre sont: palpe mandibulaire présente; lobe frontal $0.5 \times$ aussi large que la largeur maximale de la tête, avec 18 setae robustes; hanches de tous les péréopodes visibles dorsalement; yeux disposés directement sur chaque côté de la tête. Une clé pour les espèces de Halacarsantia est fournie.
\end{abstract}

Key words: Isopoda, Santiidae, new species, Gulf of Mexico.

\section{INTRODUCTION}

The Suborder Asellota are relatively common crustaceans found in freshwater, in the littoral shallow waters and in the deep ocean (Wilson, 2008). A total of 176 species of isopods are known from the Gulf of Mexico and the Caribbean Sea together (Schotte et al., 2009; Wolff \& Brandt, 2000). Isopods of the family Santiidae (Suborder Asellota, Superfamily Janiroidea) in this region are represented by Halacarsantia colombiensis Wolff and Brandt, 2000; Santia milleri (Menzies and Glynn, 1968); S. lisbethae Wolff \& Brandt, 2000 and Spinosantia muelleri Wolff \& Brandt, 2000 (Kensley \& Schotte, 1989; Kensley et al., 1997; Schotte et al., 2008; Shimomura \& Bruce, 2012; Wolff \& Brandt, 2000). During a survey of peracarid crustaceans carried out in June 2012 in the Sisal Coral Reef System, some santiid isopods were collected and studied. This material contained a new species of Halacarsantia, which is described herein.

\section{MATERIAL AND METHODS}

The host sponge was hand collected by SCUBA directly from the rocky bottom and put in a polyethylene bag. In the laboratory, some drops of alcohol-formalin were added to the sponge, previously deposited in a bucket with filtrate water to extract the sponge inhabitants. The isopods were studied with the aid of "Motic" Microscopes 
BA 210 and $102 \mathrm{M}$, both fitted with a camera lucida to assist creating the drawings. Figures were inked rendered using the program Corel Draw v.12.

RESULTS

SYSTEMATICS

Order Isopoda Latreille, 1817

Suborder Asellota Latreille, 1802

Superfamily Janiroidea Sars, 1897

Family Santiidae Wilson, 1987

Genus Halacarsantia Wolff, 1989

Halacarsantia suarezmoralesi new species Ortiz, Schotte \& Winfield (Figs. 1-4)

Material examined. Holotype: adult male $(1.3 \mathrm{~mm})$, Bocacha, Sisal Coral Reef System, Yucatan, Mexico, 04 June 2012, 2119'17.3" N, 90²0'02.6" E, from host sponge Ailochroia crassa (Hyatt, 1875), rock bottom, depth $17 \mathrm{~m}$; deposited at the Colección Nacional de Crustáceos, Instituto de Biología, UNAM, No. CNCR.28288. Paratype: female $(0.9 \mathrm{~mm}$, with 2 eggs), same data as holotype, No. CNCR.28289. Other material: 2 males (0.9-1.2 mm); 11 females with oostegites; 0.5-1.2 mm (1 with 6, 1 with 4 eggs), same data as holotype, No. CNCR.28290.

\section{Diagnosis.}

Body widest at pereonite 4; antennula halflength of antenna; mandibular palp present; frontal lobe $0.5 \times$ as wide as maximum width of head, with 18 robust setae; coxae of all pereopods dorsally visible; eyes directly settled on each side of head; with no bulging processes; with not more than 5-6 ommatidia; rostrum with 18 robust setae; margins of entire body covered with robust setae; coxae I-VII visible in dorsal view; pereopods without articular plates; pleon longer than wide; pleopod 1 distally truncate; anus exposed, not covered by pleopods; uropod with single ramus.

Description of the male holotype.

A small isopod (1.3 mm or less); body ovoid, depressed; slightly concave; head as wide as long; eyes sessile, of 4-5 ommatidea (Fig. 1 A).

Antennula. Length $0.5 \times$ antenna length: composed of six articles; with one aesthetasc; basal article widest; distal article $1.2 \times$ as length of articles 2 and 3 combined; with 4 terminal setae (Fig. 1 B).

Antenna. Article 2 not inflated; articles 2-5 equal in length; peduncle composed of two short and two long articles; article three with one broom seta; flagellum of five articles (Fig. $1 \mathrm{C}$ ).

Mandibles. Incisor with 3-4 teeth; palp article 1 as long as article 3; article 2 twice length of article 1, with one long distal and one short subdistal seta; article 3 with 2 distal setae and 3 accessory setae; left mandible with lacinia mobilis; with 5 distal teeth; lacinia mobilis on right mandible small, bearing 3 tiny teeth. (Fig. 2 A; 2 B).

Paragnaths. Outer lobes wide, distally with small setae; molar well developed

Maxillula. Outer lobe with 5 short and one long distal seta bearing setules. Inner lobe narrow, shorter than the outer one; with 3 distal setae (Fig. 2 C).

Maxilla. Outer lobe with 2 long and one short distal setae. Inner lobes with 2 and 3 distal setae. Innermost lobe widest (Fig. 2 D). 


\section{A}

B
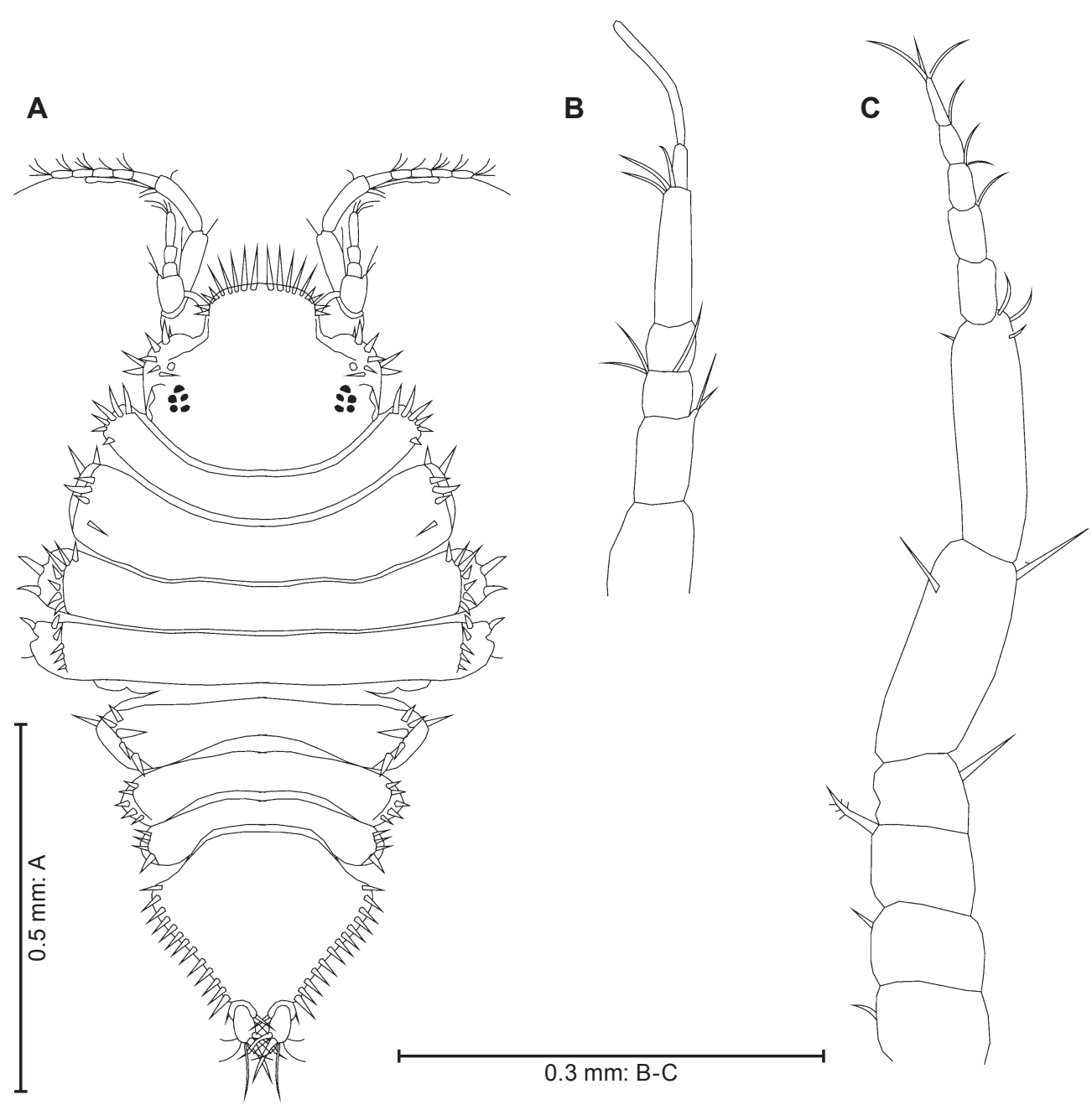

Fig. 1 - Halacarsantia suarezmoralesi sp. nov.; holotype male: A, dorsal view of body; B, antennula; $\mathrm{C}$, antenna.

Maxilliped narrow and similar in shape; article 2 with one distal seta; article 3 with one subdistal seta; article 4 with 3 subdistal setae; article 4 with 2 subdistal and 2 distal setae (Fig. 2 E). claws.

Pereopods. All without articular plate; simple setae, and dactylus with two

Pereopod I. Ischium as long as merus; merus with one robust seta on anterodistal margin; carpus with 3 robust setae on posterior margin; propodus ovoid, twice length of carpus, with 2 robust setae on posterior margin; dactyl (including claws), as long as propodus; inner claw $0.5 \times$ as long as the outer one (Fig. $3 \mathrm{~A}$ ).

Pereopod II. Ischium longer than merus; merus longer than carpus, with single robust seta each on anterodistal and posterodistal corners; carpus and propodus each with 3 robust setae on posterior margins; propodus twice length of dactyl (Fig. 3 B). 

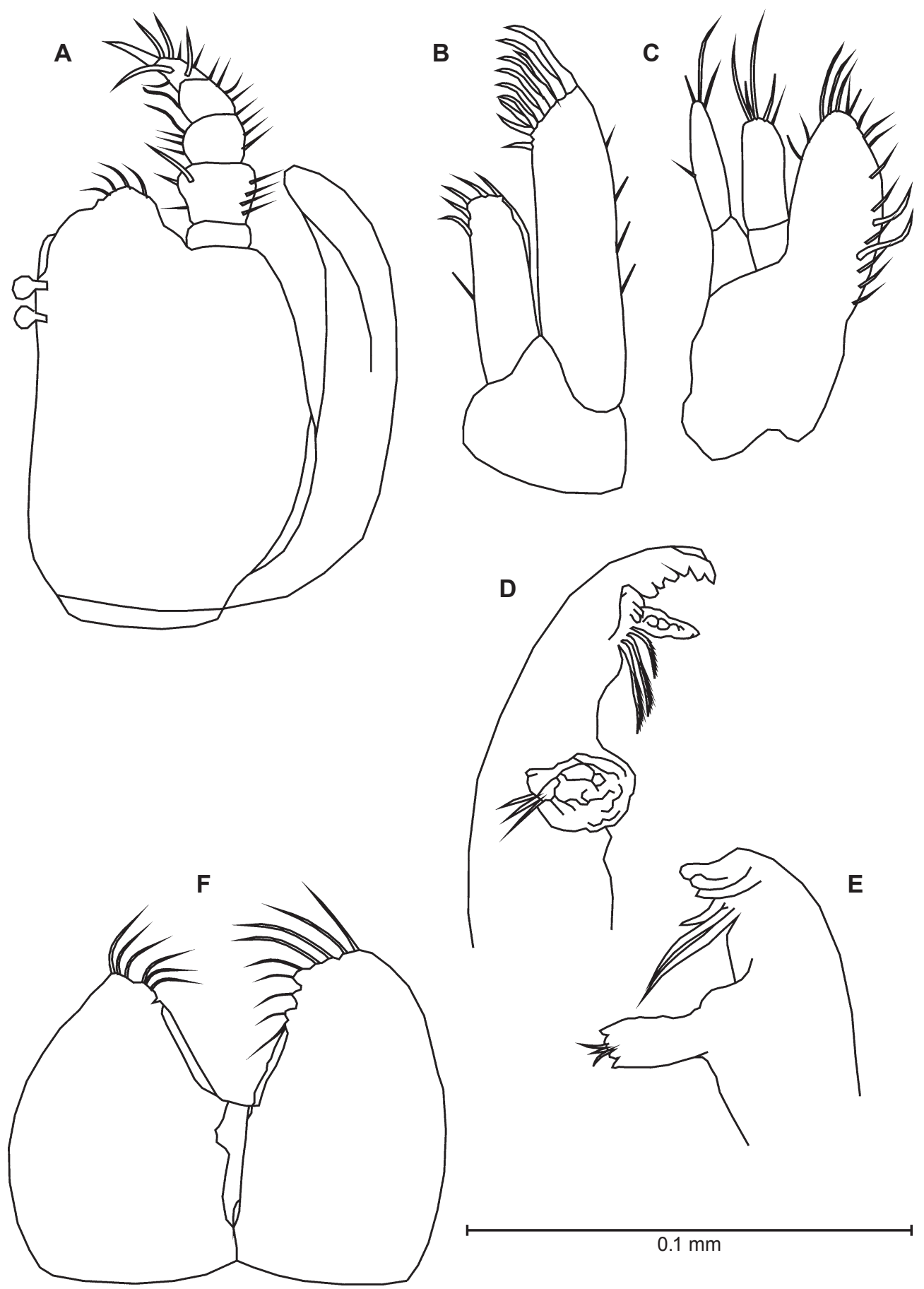

Fig. 2 - Halacarsantia suarezmoralesi sp. nov.; holotype male: A, maxilliped; B, maxilla; C, maxillule; $\mathrm{D}$, left mandible; E, right mandible; F, lower lip. 
Pereopod III. Merus longer than carpus, with 2 robust setae on anterodistal corner; carpus with one robust seta on anterodistal and 3 on posterodistal margins; propodus more than twice length of dactyl with 1 small robust setae on posterior margin (Fig. 3 C).

Pereopod $I V$. Basis with one small seta midway on posterior margin; ischium more slender than basis and merus; merus widest, with 2 robust setae on anterior margin; carpus with one long and one short setae on anterodistal margin plus two
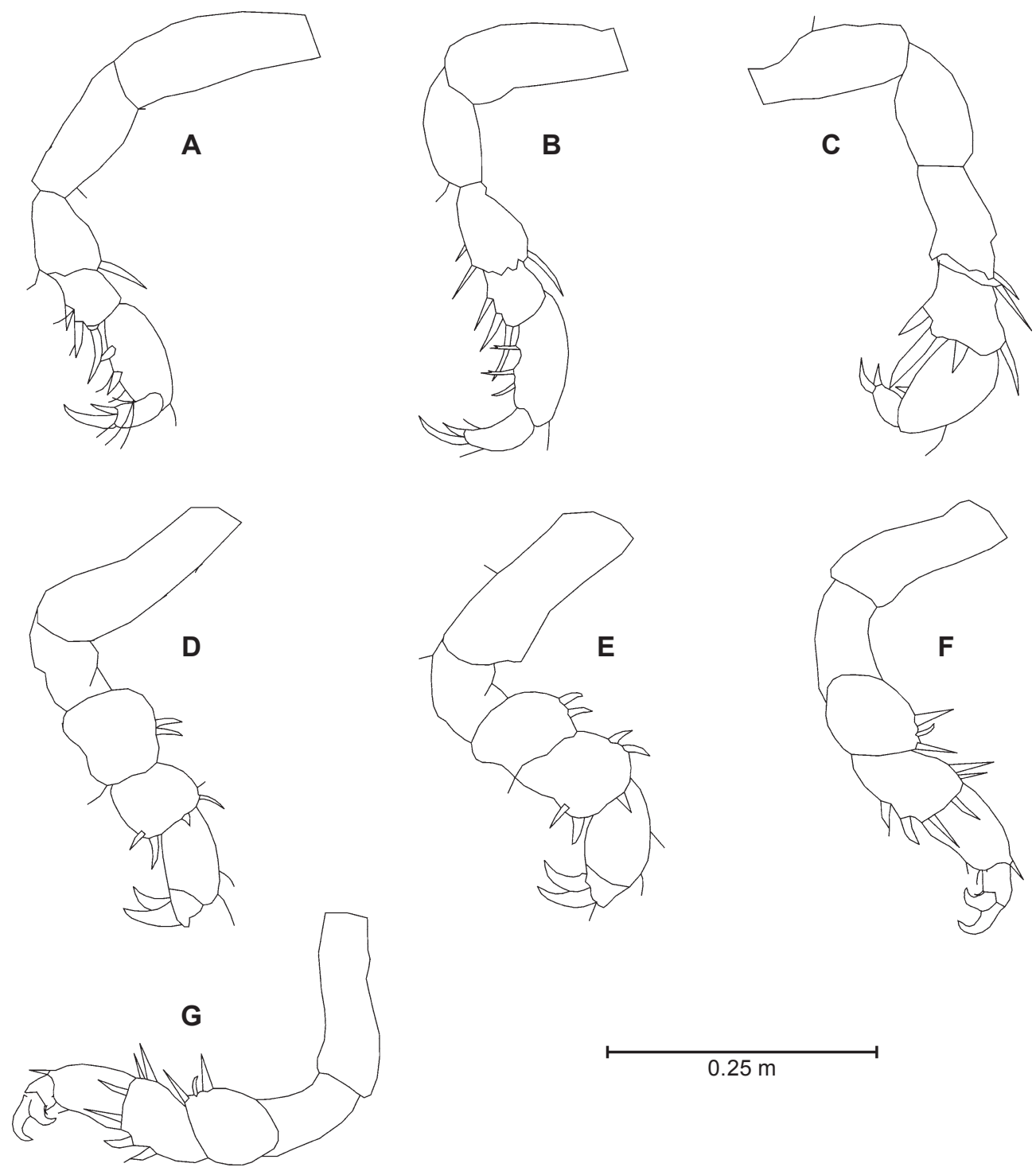

$0.25 \mathrm{~m}$

Fig. 3 - Halacarsantia suarezmoralesi sp. nov.; holotype male. A, pereopod I; B, pereopod II; C, pereopod III; D, pereopod IV; E, pereopod V; F, pereopod VI; G, Pereopod VII. 
setae on posteroventral margin and another on distal margin; propodus somewhat longer than carpus with 2 small setae on anterior margin (Fig. 3 D).

Pereopod $V$. Basis, merus and carpus wider than ischium and propodus; merus and carpus each with two robust setae on anterior margin; carpus with 2 robust setae on posterolateral margin plus one robust seta on distal margin (Fig. $3 \mathrm{E}$ ).

Pereopod VI. Basis and ischium without setae; merus and carpus each with 2 robust setae on anterior margins; carpus with 2 long and 2 short robust setae on posterior margin; propodus with one subdistal setule on each distal corner (Fig. $3 \mathrm{~F}$ ).

Pereopod VII. Basis longest; basis and ischium without setae; merus with 2 robust long and single short setae on anterior margin; carpus with 3 robust setae on posterior margin, 2 on anterolateral margin and one posterodistally (Fig. $3 \mathrm{G}$ ). (Fig. 4 A).

Pleopod I. Widest at base; $0.4 \times$ longer than wide; with 3 robust distal setae

Pleopod II. Exopod wider than endopod; tapering to apex; with one seta distally and one on inner margin; endopod narrow, elongate, tapering to acute apex; not reaching apex of exopod (Fig. 4 B).

Pleopod III. Endopod with three robust setae; exopod uniramous (Fig. 4 C).

Pleopod $I V$. Exopod twice length of endopod, distally acute with single apical seta; endopod tapering to apex, bearing one long distal seta (Fig. 4 D).

Pleopod V. Composed of single lobe; without setae, rounded apically (Fig. 4 E).

Pleotelson. Dorsally smooth; of single shield shaped segment, wider than long, tapering posteriorly, almost as wide as pereonite VII, lateral margins each bearing 13 robust, equidistant setae (Fig. 1).

Uropod. Protopod without mediodistal angle; with single robust setulate seta; basal article with one subdistal and two distal setae; distal article vestigial; with one robust, and 2 simple setae (Fig. $4 \mathrm{G}$ ).

Female is similar to male in shape; oostegites wide and thin; operculum ovoid, flat, without setae.

Remarks. The genus Halacarsantia currently contains 8 species with the inclusion of $H$. suarezmoralesi n. sp.. Only $H$. colombiensis from the southern Caribbean Sea has been recorded from the western Atlantic.

The eighth species, Halacarsantia suarezmoralesi n. sp. differs from H. justi Wolff, 1989 and $H$. setosa Shimomura \& Ariyama, 2004 in having a mandible palp (missing in $H$. justi and $H$. setosa). It differs from $H$. ovata Shimomura \& Ariyama, 2004 and $H$. colombiensis Wolff \& Brandt, 2000 by having coxae I-VII visible in dorsal view (not visible on peropods I-II and IV-VII in H. ovata). H. acuta Shimomura and Ariyama 2004 has a rostrum bearing 6 robust setae whereas the new species bears 18 robust setae. It differs from $H$. kussakini Mueller, 1992 in having 7-8 robust setae on each side of head and an antennal flagellum composed of 5 articles, in contrast to $H$. kussakini, which has 2 robust setae on each side of head and 11 articles in the antennal flagellum. Finally, H. suarezmoralesi n. sp. is separated from H. uniramea (Menzies \& Miller, 1955) because of the 18 robust setae on the rostrum (17 in $H$. uniramea). The new species, $H$. suarezmoralesi n. sp. represents the eighth species of the genus, the second known from the western Atlantic as well as being the first recorded for the Gulf of Mexico.

Shimomura \& Bruce (2012) presented a key of Halacarsantia species. Their key is given below and modified to include H. suarezmoralesi. 

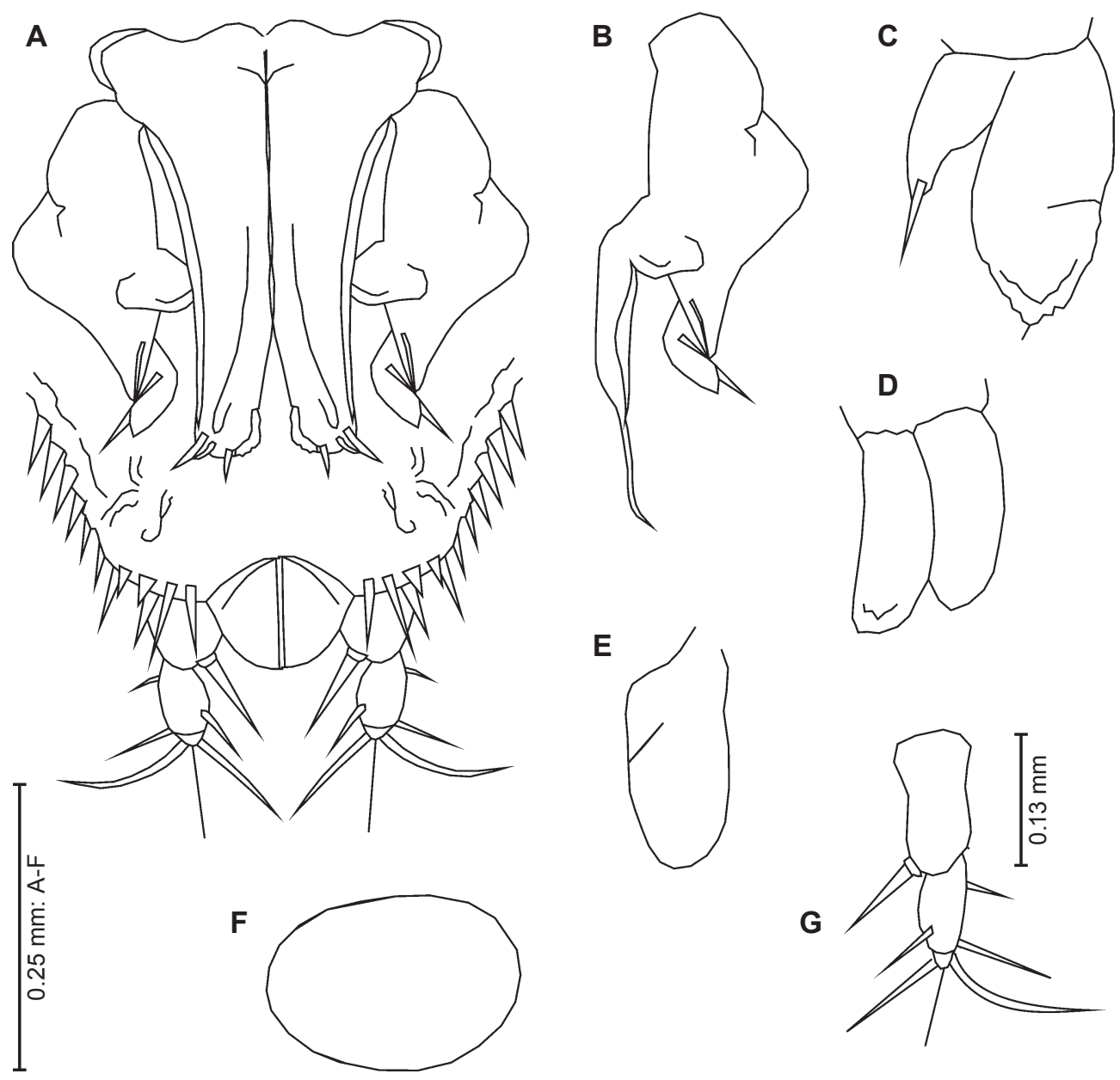

Fig. 4 - Halacarsantia suarezmoralesi sp. nov.; holotype male. A, ventral view of pleotelson to show pleopods I-II and uropod "in situ"; B, pleopod II; C, pleopod III; D, pleopod IV; E, pleopod V; F, female operculum; G, male uropod.

Key to the species of Halacarsantia

1 - Mandibular palp absent

2 - Body without dorsal robust setae

H. justi

- Body with dorsal robust setae

H. setosa

3 - Frontal lobe of head at least 0.5 times as wide as maximum width of head; pleotelson broader than long; uropods stout

- Frontal lobe of head less than 0.3 times as wide as maximum width of head; pleotelson narrower than long; uropods narrow 
4 - Coxae of pereopods I, II and IV-VII not visable dorsally; eyes without bulging processes H. ovata

- Coxal of all pereopods dorsally visible; eyes with or without bulging processes

5 - Eyes with bulging processes H. colombiensis

- Eyes without bulging processes H. suarezmoralesi $\mathrm{n}$. sp.

6 - Frontal lobe of head with 17 robust setae; antenna shorter than half length of body; pereopods V-VII broader than preceding pereopods; uropods stout $(0.3 \times$ as long as wide)

H. uniramea

- Frontal lobe of head with 6 robust setae; antenna longer than half length of body; pereopods V-VII similar to preceding pereopods; uropods slender $(0.7 \times$ as long as wide)

7 - Lateral margins of head each with 2 robust setae; antenna flagellum composed of 11 articles; maxilliped epipod apically blunt, with 2 setae ... H. kussakini

- Lateral margins of head each with 3 robust setae; antenna flagellum composed of 8 articles; maxilliped epipod apically acute, without setae H. acuta

Etymology. The species is named honoring Dr. Eduardo Suárez Morales from El Colegio de la Frontera Sur (ECOSUR), Unidad Chetumal, Quintana Roo, México, for his contributions to the knowledge of crustaceans.

\section{ACKNOWLEDGEMENTS}

We gratefully acknowledge the funds obtained through grants from the Universidad Nacional Autónoma de México (PAPIME-PE207311 and PAPCA-FESIztacala-2013 (Numeral 2) projects). The authorities of the Agriculture and Fisheries Secretariat (SAGARPA; CONAPESCADGOPA02921.290411.1172), and the Administración Portuaria Integral Progreso (API, Puerto Progreso), Yucatán, are also thanked for granting the necessary permits to sample within the coral reef. Our thanks to Dr. Angelika Brandt, Zoologisches Institut und Zoologisches Museum, Hamburg, Germany and Dr. Gary Poore, Museum Victoria, Melbourne, Australia for sending bibliographies as well. Finally, we thank in particular M.A. Lozano Aburto and C.M. Bedia Sánchez for help during the SCUBA collecting.

\section{O NOUĂ SPECIE A GENULUI HALACARSANTIA (CRUSTACEA, ISOPODA, ASELLOTA) DIN RECIFUL DE CORALI SISAL, YUCATAN, MEXIC}

\section{REZUMAT}

Familia Santiidae conţine în prezent 5 genuri cu 29 de specii, fiind inclusă în Subordinul Asellota. În partea de nord-vest a Oceanului Atlantic această familie este reprezentată numai de genurile Santia (2 specii), Halacarsantia (1 specie) şi Spinosantia (1 specie). Prezentul studiu reprezintă descrierea unei specii noi din genul Halacarsantia, pe baza materialului colectat din Reciful de Corali Sisal, din Yucatan, Veracruz. Această nouă specie a genului Halacarsantia reprezintă cea de a 29-a specie de isopod asellot descris din Golful Mexic şi ridicând la opt numărul de specii din acest gen, cunoscute până în present. Cele mai importante diferențe existente între această nouă specie şi speciile deja descrise din cadrul genului Halacarsantia sunt: palpul mandibular prezent; lobul frontal $0.5 \times$ mai lat decât lungimea maximă a capului, lobul frontal cu 18 sete subţiri; coxele şi pereopodele dorsale vizibile; ochii aşezaţi direct pe fiecare parte a capului. În lucrare este prezentată, de asemenea, şi o cheie de determinare a speciei.

\section{LITERATURE CITED}

KENSLEY, B., M. ORTIZ, M. SCHOTTE, 1997 - New records of marine Isopoda from Cuba (Crustacea, Peracarida). Proceedings of the Biological Society of Washington, 110 (1): 74-98. 
KENSLEY, B., M. SCHOTTE, 1989 - Guide to the Marine Isopod Crustaceans of the Caribbean. Smithsonian Institution Press, Washington, D. C. and London. 308 pp.

SCHOTTE, M., C.B. BOYKO, N.L. BRUCE, G.C.B. POORE, S. TAITI, G.D.F. WILSON, 2008 World List of Marine Freshwater and terrestrial Isopod Crustaceans (available from http:// www.marinespecies.org/isopoda) (accessed 11/2013).

SCHOTTE, M., J.C. MARKHAM, G.D.F. WILSON, 2009 - Isopoda (Crustacea) of the Gulf of Mexico. In Gulf of Mexico Origins, Waters and Marine Life, ed. D. L. Felder and D. K. Camp, pp. 973-986: Texas A\&M University Press College Station, TX.

SHIMOMURA, M., N.L. BRUCE, 2012 - A new species of Halacarsantia Wolff, 1989 (Crustacea, Isopoda, Asellota, Santiidae) from Wistari Reef, southern Great Barrier Reef, Australia. ZooKeys, 173 (2314): 1-9.

WILSON, G.D.F., 2008 - Local and regional species diversity of benthic Isopoda (Crustacea) in the deep Gulf of Mexico. Deep-Sea Research II, 55: 2634-2649.

WOLFF, T., A. BRANDT, 2000 - Caribbean species of Munnidae, Paramunnidae and Santiidae (Isopoda: Asellota). Steenstrupia, 25 (1): 121-146.

Received: January 30, 2015

Accepted: March 12, 2015
Manuel Ortiz, Ignacio Winfield

Laboratorio de Crustáceos, Edificio L-4,

Facultad de Estudios Superiores Iztacala,

Universidad Nacional Autónoma de México, Ave. De los Barrios no. 1, Tlalnepantla,

Estado de Mexico, C.P.

e-mails: ortiztouzet@yahoo.com ignacioc@unam.mx

Marilyn Schotte

Dept. of Invertebrate Zoology, NHB 163,

Smithsonian Institution, Washington, DC, USA

e-mail: schottem@si.edu 